Int. J. Morphol.,

29(3):988-991, 2011.

\title{
Cystadenocarcinoma Arising from Ovary in a Three Year Old Doberman Bitch
}

\author{
Cistoadenocarcinoma Derivado del Ovario en una Perra Doberman de Tres Años
}

\author{
${ }^{*}$ A. Temitope Ajadi; **E. Richard Antia \& ${ }^{* * *}$ E. Effiong Akang
}

\begin{abstract}
AJADI, A. T.; ANTIA, E. R. \& AKANG, E. F. Cystadenocarcinoma arising from ovary in a three year old doberman bitch. Int. J. Morphol., 29(3):988-991, 2011.

SUMMARY: A three- year- old Doberman was presented with complaint of lethargy and weight- loss. Physical examination revealed a mass in the right abdomen. Laboratory abnormalities included anaemia, azotaemia and metabolic acidosis. Sonogram of the mass was an anaechoic area surrounded by hypoechoic tissue. The mass was located between the right kidney and ovary and showed papillary and tubular pattern of cystadenocarcinoma. Nephroureterectomy and ovariohysterectomy was performed; however bitch was euthanized owing to poor improvement, while necropsy of the left kidney revealed an end-stage kidney. It was concluded that the cystadenocarcinoma must have arisen secondary to a primary ovarian adenocarcinoma through stromal invasion.
\end{abstract}

KEY WORDS: Ovary; Cystadenocarcinoma; Doberman; Dog.

\section{INTRODUCTION}

Primary ovarian tumors are uncommon in domestic animals. Incidence of ovarian tumors in dogs ranges between 1-6 percent (Yotov et al., 2005). Epithelia tumors are more common and account for 46 percent of canine ovarian tumors (Hori et al., 2006). The exact cause of ovarian tumor is unknown. In humans, mutations of BRCA1 and BRCA2 genes have been shown to account for $5-15 \%$ of ovarian tumors (Lakhani et al., 2004). In dogs, epithelial tumors of the ovary have been induced in bitches given diethylstilbesterol for prolonged periods (Maclachlan, 1987).

Cystadenocarcinoma is the commonest ovarian epithelial tumor in dogs (Yotov et al.). The tumor consist of arboriform papillae that project into the cyst. Ovarian cystadenocarcinoma could affect both ovaries and signs may include abdominal enlargement, vulva discharge, weight loss and lethargy (Sforna et al., 2003). Most ovarian cystadenocarcinoma are unilateral but often spread transcoelomically, through the ovarian capsule with subsequent implantation in the abdominal cavity (Maclachlan). This paper presents a case of an inbred three year old Doberman with chronic weight loss and unthriftiness, diagnosed with cystadenocarcinoma of the ovary.

\section{CASE REPORT}

A three year old female Doberman was presented to Petcare Animal Hospital with complaints of unthriftiness, lethargy and progressive weight loss. Physical examination revealed that the dog was moderately dehydrated with bilateral mucopurulent ocular discharge. There was moderate abdominal distension around the fourth and sixth lumbar vertebrae and palpation yielded firm, painless mass from which $5 \mathrm{mls}$ of serosanguineous fluid was aspirated.

Blood was obtained from the cephalic vein for complete blood counts, serum creatinine, blood urea nitrogen and electrolytes prior to and after exploratory laparotomy. Transcutaneous abdominal ultrasound was performed with a 3.5 MHz sector transducer using a portable ultrasound machine (Kaixin KX 2000R, Xuzhou, China). Exploratory laparotomy was performed to confirm diagnosis. This was followed by unilateral nephroureterectomy and ovariohysterectomy. The dog was premedicated with intramuscular injections of $0.03 \mathrm{mg} / \mathrm{kg}$ atropine (AtocanR, Sinochem, China) and $0.5 \mathrm{mg} / \mathrm{kg}$ of diazepam (CalmposeR, Ranbaxy, India). Anaesthesia was maintained with $10 \mathrm{mg} /$ $\mathrm{kg}$ intravenous injections of $6 \%$ sodium Pentobarbitone (Kyron laboratories, Benrose, U. S. A). Laparotomy was

\footnotetext{
* Department of Veterinary Public Health \& Reproduction, University of Agriculture, Abeokuta, Ogun State, Nigeria.

** Department of Veterinary Pathology, University of Ibadan, Ibadan, Oyo State, Nigeria.

**** Department of Pathology, College of Medicine, University of Ibadan, Ibadan, Nigeria.
} 
done using ventral midline approach, while nephroureterectomy and ovariohysterectomy were performed using standard techniques. Dog was euthanized due to poor renal function nine days later. Necropsy was thereafter performed and samples of the contralateral kidney and the liver were obtained and submitted to histopathology.

The dog had mild normochromic, normocytic anaemia with moderate lymphocytic leukocytosis (Table I). The BUN, creatinine and electrolytes were all elevated and progressively worsened throughout the monitoring period. Transcutaneous abdominal ultrasound of the dog (Fig. 1)

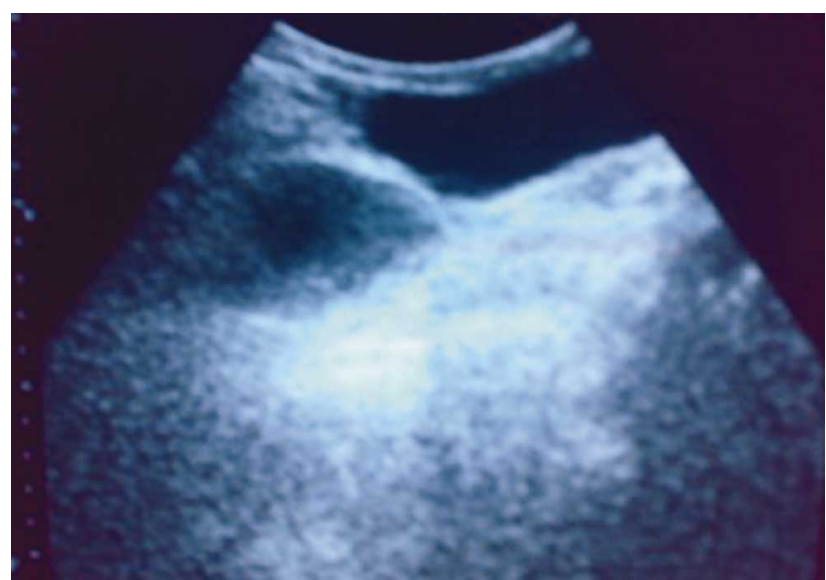

Fig. 1. Transcutaneous abdominal ultrasound of an inbred female Doberman showing an oval shaped hypoechoic mass lying proximal to the bladder. revealed an oval shaped mass between the bladder and the caudal pole of the right kidney. The mass had central anechoic area surrounded by hypoechoic tissues. In addition, the kidneys showed enhanced cortico- medullary distinction.

Following laparotomy, the mass (Fig. 2) was located at the right half of the abdominal cavity, attached to the caudal pole of the kidney, with the distended right ureter running on the ventral surface of the mass. The mass was oval in shape and well vascularized. The right ovary was attached to the mass through a thin connective tissue, while the uterine horns had multiple nodules. Other abdominal organs were essentially normal. Recovery from surgery was prolonged. At necropsy, the lungs were normal with no evidence of

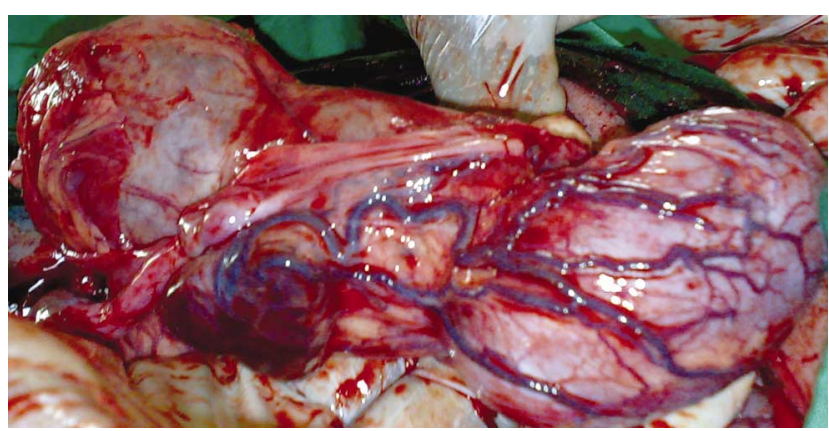

Fig. 2. Abdominal picture of a female Doberman following laparotomy showing an oval shaped mass attached to the caudal border of the right kidney. Note the rich vascular supply to the renal capsule and the capsule of the mass and the right ovary attached to the mass.
Table I. Haematology and serum chemistry of an inbred female Doberman with renal and ovarian cystadenocarcinoma. ND: Not Determined.

\begin{tabular}{lccc}
\hline Parameters & $\begin{array}{c}\text { Day of } \\
\text { presentation }\end{array}$ & $\begin{array}{c}\text { Day of } \\
\text { nephrectomy }\end{array}$ & $\begin{array}{c}\text { Day seven post } \\
\text { nephrectomy }\end{array}$ \\
\hline PCV (\%) & 29 & 28 & 29 \\
Hb (mg/dl) & 9.7 & 9.7 & 9.7 \\
RBC (X1012) & 5.3 & 5.2 & 5.4 \\
WBC (X10) & 18.6 & 19.8 & 20.5 \\
Neutrophils (\%) & 63 & 68 & 72 \\
Lymphocytes (\%) & 35 & 32 & 28 \\
Eosinophils (\%) & 0 & 0 & 0 \\
Basophils (\%) & 0 & 0 & 0 \\
Monocytes (\%) & 2 & 0 & 0 \\
BUN (mg/dl) & 204 & ND & 234 \\
Creatinine (mg/dl) & 9.8 & ND & 12.6 \\
Sodium (mmol/L) & 158 & ND & 162 \\
Potassium (mmol/L) & 12 & ND & 12 \\
Chloride (mmol/L) & 110 & ND & 112 \\
Bicarbonate ND (mmol/L) & 15 & ND & 16 \\
\hline
\end{tabular}

milliary nodules. There were multiple foci of necrosis in the liver and left kidney. Other organs appeared essentially normal. Histopathology of the mass (Fig. 3) showed papillary and tubular pattern of cystadenocarcinoma. The papillary projections and tubules were lined by pleomorphic, cuboidal to columnar epithelial cells. The cells were small, with somewhat basophilic, nonvacuolated cytoplasm. Their nuclei were round to oval and contained prominent single or double nucleoli. The mitotic rate was high. There was necrosis of tissue far from blood vessels. In addition, degeneration, haemorrhage and oedema were observed in the sub-epithelium connective tissue of the proximal ureter. The histopathology of the right ovary showed arboriform papillae comprising multiple layers of cuboidal to columnar epithelial cells, while the uterus showed similar pattern (Fig 4). 


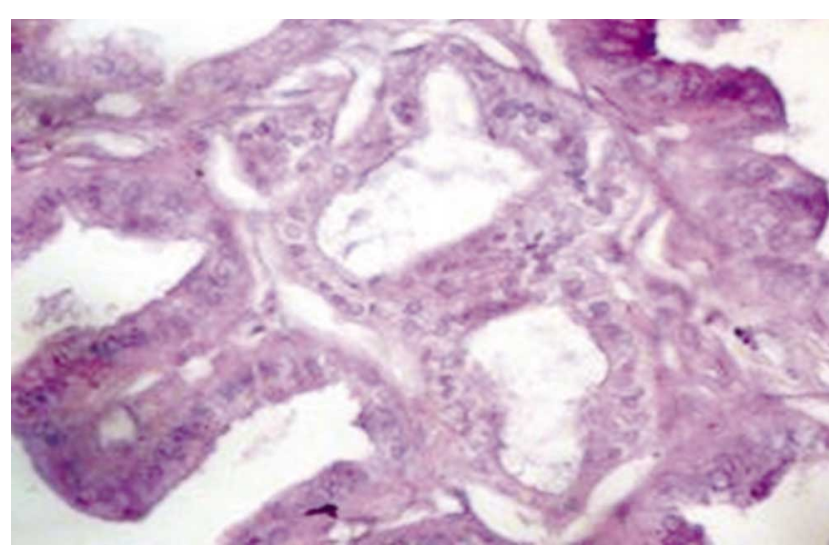

Fig. 3. Cystadenocarcinoma, papillary pattern, with projections lined by columnar epithelium. H \& E 400X.

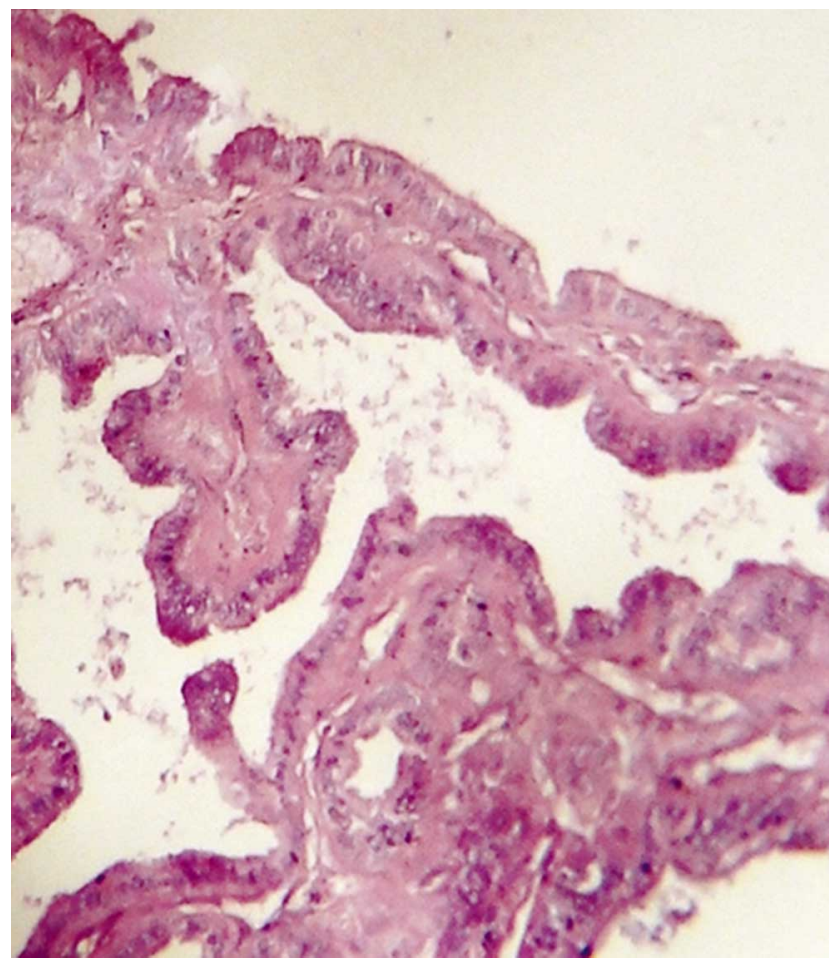

Fig. 4. Ovarian adenocarcinoma, papillary pattern, with projections lined by columnar epithelium. H \& E 400X.

\section{DISCUSSION}

This is probably the first reported case of cystadenocarcinoma arising from the ovary in Doberman and was characterized by progressive weight-loss, lethargy, dehydration, abdominal mass, azotaemia, non-regenerative anaemia with an end stage renal failure. Inbreeding increases the manifestations of genes or gene complexes responsible for genetic susceptibility to certain types of cancers. In humans, inbreeding has been associated with increased incidence of cancers of the bladder, breast, ovary and large bowel (Thompson et al., 2005; Denic et al., 2006). Although most cases of ovarian cystadenocarcinoma seem to occur sporadically, BRCA1 and BRCA2 genes account for 5-13 percent of ovarian cancers in humans (Lakhani et al.). This case suggests the possible relationship between inbreeding and the development of canine ovarian tumor, since the dog in question was a product of accidental mating of the mother by its offspring. Although other extrinsic factors associated with carcinogenesis cannot be ruled out, their likelihood is very remote because this bitch was never on hormonal therapy at any time.

Ovarian cystadenocarcinoma have been associated with hypercalcemia and increased levels of serum parathyroid hormone- related proteins (Hori et al.). The haematological findings in this dog were a mild normochromic normocytic anaemia that failed to improve even after nephrectomy. The moderate lymphocytic leukocytosis might have occurred secondary to increased production of interleukins because of necrosis in the neoplastic tissues. Other biochemical abnormalities in this dog such as azotaemia, hyperkalemia, hypernatremia and metabolic acidosis have been reported in renal tumors and are probably associated with the severity of renal insufficiency (Bryan et al., 2006).

The sonographic pattern of the tumor mass in this dog was a central anaechoic cavity surrounded by hypoechoic components. This may be associated with the cystic nature of the mass. In addition, the kidney showed increased corticomedullary distinction probably as a result of the associated hydronephrosis. The ovary was not recognized on abdominal ultrasound probably because it was not enlarged while the uterine sonogram was consistent with localized cystic endometrial hyperplasia.

Nephroureterectomy is the recommended technique for definitive treatment of all malignant renal and ureteral tumors except lymphosarcoma (Bukowski \& Novick, 1997), while ovariohysterectomy is the treatment option for ovarian cystadenocarcinoma (Yotov et al.; Hori et al.). In this dog, both ovariohysterectomy and unilateral nephrouretectomy was performed so as to remove the affected kidney, renal mass and the attached ovary and uterus. However, the outcome of the surgery was considered unsatisfactory due to the persistent azotaemia, vomition and anorexia which necessitated the euthanasia. The poor outcome might have been associated with the reduced function of the contralateral kidney which was shown at necropsy to be approaching an end stage kidney. The chronic renal disease in this dog may be due to necrosis occasioned by metastatic tumor or further damage secondary to the inability of the kidney to excrete urea. Renal transplant should have been considered to improve the renal function, but cost might not have allowed this. 
Finally, renal cystadenocarcinoma has been reported in German Shepherds and Golden Retrievers as an autosomal dominant condition and associated with nodular dermatofibrosis and uterine leiyomyoma (Moe \& Lium, 1997). Renal cystadenocarcinoma are always bilateral, and the deterioration of renal function is slowly progressive. Till now, renal cystadenocarcinoma has not been reported in the Doberman. In addition, this dog did not have any nodular cutaneous lesion to suggest that the case of this Doberman is same as the usual renal cystadenocarcinoma of the German Shepherd dog. In addition, the histology of the tumor mass and the ovarian tissue from this dog were similar and essentially composed of papillary projections and tubules that were lined by pleomorphic, cuboidal to columnar epithelial cells. Since ovarian metastases of renal tumors are rare it was therefore concluded that the mass must have arisen from the ovarian cystadenocarcinoma probably due to stromal invasion.

ACKNOWLEDGEMENTS. The authors are grateful to Dr. Kunle Abiade of Petcare Animal Hospital for providing the case and to Dr. Ajadi Adetola of the Department of Veterinary Medicine \& Surgery, UNAAB for performing the ultrasound examination.

AJADI, A. T.; ANTIA, E. R. \& AKANG, E. F. Cistoadenocarcinoma derivado del ovario en una perra doberman de tres años. Int. J. Morphol., 29(3):988-991, 2011.

RESUMEN: Se presentó una perra doberman de tres años de edad aquejada de letargo y pérdida de peso. El examen físico reveló una masa en el abdomen derecho. El examen de laboratorio mostró anormalidades que incluyeron anemia, azotemia y acidosis metabólica. La ecografía de la masa mostró un área anecoica rodeada por tejido hipoecoico. La masa se localizó entre el riñón derecho y ovario y mostró el patrón papilar y tubular del cistoadenocarcinoma. Se realizó la nefroureterectomía y ovariohisterectomía, sin embargo la perra fue sacrificada debido a la falta de mejoría, donde la autopsia del riñón izquierdo reveló un riñón en etapa terminal. Se concluyó que el cistoadenocarcinoma debió haber surgido secundario a un adenocarcinoma primario de ovario a través de la invasión del estroma.

PALABRAS CLAVE: Ovario; Cistoadenocarcinoma; Doberman; Perro.

\section{REFERENCES}

Bryan, J. N.; Henry, C. J.; Turnquist, S. E.; Tyler, J. W.; Liptak, J. M.; Rizzo, S. A.; Sfiligoi, G.; Steinberg, S. J.; Smith, A. N. \& Jackson, T. Primary renal neoplasia of dogs. J. Vet. Intern. Med., 20(5):1155-60, 2006.

Bukowski, R. M. \& Novick, A. C. Clinical practice guidelines: renal cell carcinoma. Cleve. Clin. J. Med., 64(Suppl 1):SI144; quiz SI45-7, 1997.

Denic, S.; Frampton, C. \& Nicholls, M. G. Risk of cancer in an inbred population. Cancer Detect. Prev., 31(4):263-9, 2007.

Hori, Y.; Uechi, M.; Kanakubo, K.; Sano, T. \& Oyamada, T. Canine ovarian serous papillary adenocarcinoma with neoplastic hypercalcemia. J. Vet. Med. Sci., 68(9):979-82, 2006.

Lakhani, S. R.; Manek, S.; Penault-Llorca, F.; Flanagan, A.; Arnout, L.; Merrett, S.; McGuffog, L.; Steele, D.; Devilee, P.; Klijn, J. G.; Meijers-Heijboer, H.; Radice, P.; Pilotti, S.; Nevanlinna, H.; Butzow, R.; Sobol, H.; Jacquemier, J.; Lyonet, D. S.; Neuhausen, S. L.; Weber, B.; Wagner, T.; Winqvist, R.; Bignon, Y. J.; Monti, F.; Schmitt, F.; Lenoir, G.; Seitz, S.; Hamman, U.; Pharoah, P.; Lane, G.; Ponder, B.; Bishop, D. T. \& Easton, D. F. Pathology of ovarian cancers in BRCA1 and BRCA2 carriers. Clin. Cancer Res., 10(7):2473-81, 2004.

MacLachlan, N. J. Ovarian disorders in domestic animals. Environ. Health Perspect., 73:27-33, 1987.
Moe, L. \& Lium, B. Hereditary multifocal renal cystadenocarcinomas and nodular dermatofibrosis in 51 German Shepherd dogs. J. Small Anim. Pract., 38(11):498-505, 1997.

Sforna, M.; Brachelente, C.; Lepri, E. \& Mechelli, L. Canine ovarian tumours: a retrospective study of 49 cases. Vet. Res. Commun., 27(Suppl 1):359-61, 2003.

Thomson, S. A.; Kennerly, E.; Olby, N.; Mickelson, J. R.; Hoffmann, D. E.; Dickinson, P. J.; Gibson, G. \& Breen, M. Microarray analysis of differentially expressed genes of primary tumors in the canine central nervous system. Vet. Pathol., 42(5):550-8, 2005.

Yotov, S.; Simeonov, R.; Dimitrov, F.; Vassilev, N.; Dimitrov, M. \& Georgiev, P. Papillary ovarian cystadenocarcinoma in a dog. J. S. Afr. Vet. Assoc., 76(1):43-5, 2005.

Correspondence to:

Ayisat Temitope Ajadi

Department of Veterinary Public Health \& Reproduction

University of Agriculture

Abeokuta, P.M.B 2240, Alabata road

Abeokuta, Ogun State

NIGERIA

Tel: 234-803-956-0868

Email: ayisat_ajadi@yahoo.com

Received: 02-03-2011

Accepted: 26-04-2011 